\section{Sedimentary}

\section{Research}

Journal of Sedimentary Research, 2012, v. 82, 1006-1016

Current Ripples

DOI: $10.2110 /$ jsr.2012.85

\title{
DETERMINING THE DIAGENETIC CONDITIONS OF CONCRETION FORMATION: ASSESSING TEMPERATURES AND PORE WATERS USING CLUMPED ISOTOPES
}

\author{
SEAN J. LOYD,${ }^{1}$ FRANK A. CORSETTI ${ }^{2}$ JOHN M. EILER, ${ }^{3}$ AND ARADHNA K. TRIPATI ${ }^{1,3}$ \\ ${ }^{1}$ Department of Earth and Space Sciences, University of California, Los Angeles, 595 Charles Young Drive East, Los Angeles, California 90095, U.S.A. \\ ${ }^{2}$ Department of Earth Sciences, University of Southern California, 3651 Trousdale Avenue, Los Angeles, California 90089, U.S.A. \\ ${ }^{3}$ Division of Geological and Planetary Sciences, California Institute of Technology, 1200 East California Boulevard, Pasadena, California 91125, U.S.A. \\ e-mail: seanloyd@ess.ucla.edu
}

\begin{abstract}
Carbonate- $\delta^{18} \mathrm{O}$ paleothermometry is used in many diagenetic studies to unravel the thermal history of basins. However, this approach generally requires an assumed pore-water $\delta^{18} \mathrm{O}\left(\delta^{18} \mathrm{O}_{\text {pw }}\right)$ value, a parameter that is difficult to quantify in past regimes. In addition, many processes can change the original isotopic composition of pore water, which further complicates the assignment of an initial $\delta^{18} \mathrm{O}_{\mathrm{pw}}$ and can lead to erroneous temperature estimates. Here, we use clumped-isotope thermometry, a proxy based on the ${ }^{13} \mathrm{C}^{18} \mathrm{O}$ bond abundance in carbonate minerals, to evaluate the temperatures of concretion formation in the Miocene Monterey Formation and the Cretaceous Holz Shale, California. These temperatures are combined with established carbonate-water fractionation factors to calculate the associated $\delta^{18} \mathrm{O}_{\mathrm{pw}}$.

Results demonstrate that diagenetic processes can modify the $\delta^{18} \mathrm{O}$ of ancient pore water, confounding attempts to estimate diagenetic temperatures using standard approaches. Clumped-isotope-based temperature estimates for Monterey Formation concretions range from $\sim 17$ to $35^{\circ} \mathrm{C}$, up to $\sim 12^{\circ} \mathrm{C}$ higher than traditional $\delta^{18} \mathrm{O}$ carbonate-water paleothermometry when $\delta^{18} \mathrm{O}_{\mathrm{pw}}$ values are assumed to equal Miocene seawater values. Calculated $\delta^{18} \mathrm{O}_{\mathrm{pw}}$ values range from +0.3 to $+2.5 \%$ (VSMOW) - higher than coeval Miocene seawater, likely due to $\delta^{18} \mathrm{O}_{\mathrm{pw}}$ modification accompanying diagenesis of sedimentary siliceous phases. Clumped-isotope temperatures for the Holz Shale concretions range from $\sim 33$ to $44^{\circ} \mathrm{C}$, about 15 to $30^{\circ} \mathrm{C}$ lower than temperatures derived using the traditional method. Calculated $\delta^{18} \mathrm{O}_{\mathrm{pw}}$ values range from $-\mathbf{5 . 0}$ to $-2.9 \%$ and likely reflect the influx of meteoric fluids. We conclude that the use of clumped isotopes both improves the accuracy of temperature reconstructions and provides insight into the evolution of $\delta^{18} \mathrm{O}_{\mathrm{pw}}$ during diagenesis, addressing a longstanding conundrum in basin-evolution research.
\end{abstract}

\section{INTRODUCTION}

Carbonate is a common cementing material in sedimentary rocks, and the precipitation of carbonate cements is an important agent of lithification. In siliciclastic rocks, carbonate cementation may be spatially discontinuous, producing conspicuous structures called concretions. Concretions commonly exhibit textural characteristics such as deflection of external laminae, and variable carbonate $\delta^{13} \mathrm{C}\left(\delta^{13} \mathrm{C}_{\text {carb }}\right)$ values (Claypool and Kaplan 1974; Mozley and Burns 1993), suggesting that at least partial precipitation occurred relatively early and during progressive degradation of sedimentary organic matter. Carbonate concretions are recognized in Phanerozoic sedimentary units of nearly all ages and depositional environments, including those of the Miocene Monterey Formation and Upper Cretaceous Holz Shale of California (Fig. 1). Given their diagenetic origin, concretions may plausibly form over a broad range of temperatures - from seafloor values that are near bottom water temperatures $\left(\sim 0-5^{\circ} \mathrm{C}\right)$ to $100^{\circ} \mathrm{C}$ or more.

The differences between the oxygen isotope compositions of carbonate minerals $\left(\delta^{18} \mathrm{O}_{\text {carb }}\right)$ and the fluids from which they precipitate is related to the temperature of mineralization (Urey 1947). The most up-to-date estimates of the temperature dependence of oxygen isotope fractionation for calcite (Kim and O’Neil 1997) and dolomite (Vasconcelos et al. 2005) are

$$
1000 \ln \alpha_{\text {calcite-water }}=\left(18.03 \times 10^{3}\right) \mathrm{T}^{-1}-32.42
$$

$$
1000 \ln \alpha_{\text {dolomite-water }}=\left(2.73 \times 10^{6}\right) \mathrm{T}^{-2}+0.26
$$

where $\mathrm{T}$ represents the precipitation temperature in kelvins, and $\alpha_{\text {calcite-water }}$ and $\alpha_{\text {dolomite-water }}$ are the oxygen isotope fractionation factors between calcite and water and dolomite and water, respectively. This temperaturedependent fractionation has been applied to concretions to estimate their formation temperatures, where the oxygen isotope composition of the fluid from which the carbonate grew-an unknown parameter-is predicted. The oxygen isotope composition of pore water $\left(\delta^{18} \mathrm{O}_{\mathrm{pw}}\right)$ in sediments can be extremely variable and remains poorly constrained in most subsurface environments (Clayton et al. 1966; Hitchon and Friedman 1969; Perry et al. 1976; Hesse and Harrison 1981; Allan and Mathews 1982; Morton and Land 1987; Wilkinson et al. 1992; Behl and Garrison 1994; Bohrmann et al. 1998). In the case of concretions in marine sediments, many studies have generally assumed a $\delta^{18} \mathrm{O}_{\mathrm{pw}}$ equal to the mean value of contemporaneous seawater when calculating precipitation temperatures (i.e., Hudson 1978; Kushnir and Kastner 1984; Hennessy and Knauth; 1985; Burns and Baker 1987; Dix and Mullins 1987; Astin and Scotchman 1988; Thyne and Boles 


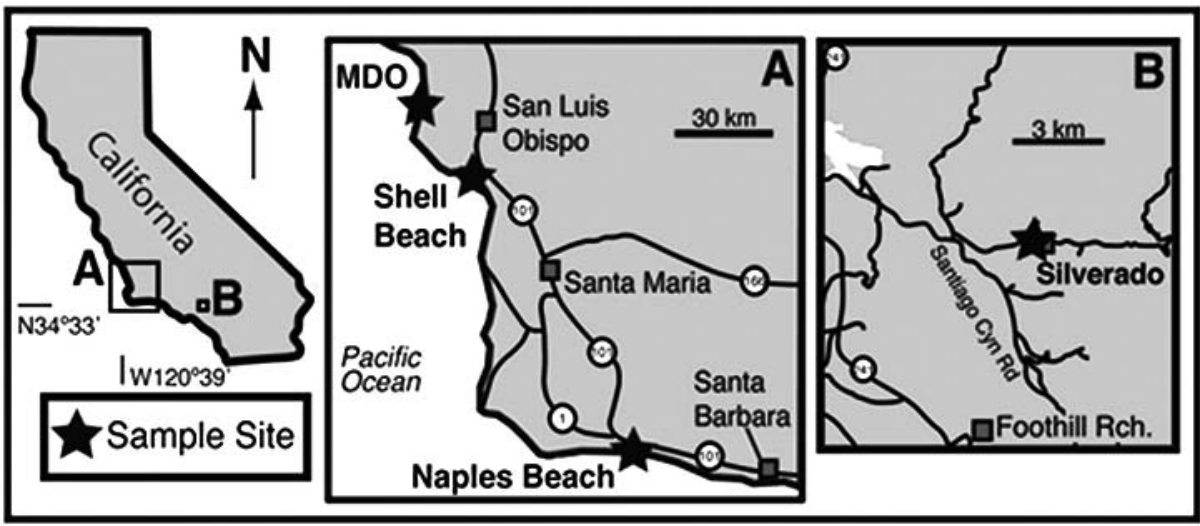

FIG. 1.-Study site locations. The insets in the map of California indicate the general areas of Parts A and B. A) Monterey Formation and B) Holz Shale localities. MDO = Montaña de Oro.

1989; Morad and Eshete 1990). However, sedimentary processes that affect $\delta^{18} \mathrm{O}_{\mathrm{pw}}$ values can invalidate this assumption. In fact, previous researchers have recognized anomalously low $\delta^{18} \mathrm{O}_{\text {carb }}$ values in carbonate concretions (Hudson and Friedman 1974; Hudson 1978; Irwin et al. 1980; Coleman and Raiswell 1981; Burns and Baker 1987; Mozley and Burns 1993). These authors have stressed the unlikelihood of precipitation at high temperatures as the cause, largely due to the presence of shallow indicators (e.g., laminae deflection, high minuscement porosity, etc.) and inferred the influence of processes that lead to depleted $\delta^{18} \mathrm{O}_{\mathrm{pw}}$. Raiswell and Fisher (2000) summarized the apparent disagreement among these shallow indicators and actual concretion formation depths (and temperatures). Some authors have suggested specific mechanisms responsible for the isotopic depletions; however, without a method by which to isolate the effects of temperature from $\delta^{18} \mathrm{O}_{\mathrm{pw}}$, the interpretations are somewhat speculative.

Carbonate clumped-isotope thermometry can be used to constrain the temperatures of carbonate growth independently of fluid $\delta^{18} \mathrm{O}$, and thus offers a way to 1) determine the temperature of carbonate formation and 2) unambiguously calculate the ancient fluid $\delta^{18} \mathrm{O}$ (Ghosh et al. 2006; Schauble et al. 2006; Eiler 2007; Eagle et al. 2010; Tripati et al. 2010; Eiler 2011), including $\delta^{18} \mathrm{O}_{\mathrm{pw}}$ (Huntington et al. 2011). The abundance of mass $47 \mathrm{CO}_{2}$ (mostly the ${ }^{13} \mathrm{C}_{-}{ }^{18} \mathrm{O}-{ }^{16} \mathrm{O}$ isotopologue) that is produced upon phosphoric-acid digestion of carbonate minerals is reported using the notation $\Delta_{47}$, and represents the abundance of this isotopologue in a sample relative to a stochastic distribution (in units of permil, \%0). Theoretical (Schauble et al. 2006; Guo et al. 2009; Eagle et al. 2010), experimental (Ghosh et al. 2006), and field-based (Ghosh et al. 2006; Eagle et al. 2010; Tripati et al. 2010; Thiagarajan et al. 2011; Zaarur et al. 2011) studies have shown that values of $\Delta_{47}$ in calcite, aragonite, and dolomite are inversely correlated to the temperature of carbonate precipitation. These temperatures can be combined with $\delta^{18} \mathrm{O}_{\text {carb }}$ values to calculate $\delta^{18} \mathrm{O}_{\text {fluid }}$, an approach that has been applied recently to study dolomitized limestones of the Latemar carbonate buildup (Ferry et al. 2011) and Eocene diagenetic cements (Huntington et al. 2011). However, these studies involved dominantly calcareous hosts, whereas this study presents findings from entirely diagenetic "first-precipitates" (that is, phases that do not likely result from recrystallization of a precursory phase) within siliciclastic hosts. Due to the siliciclastic nature of the host deposits, these concretions represent an excellent opportunity to identify ancient $\delta^{18} \mathrm{O}_{\mathrm{pw}}$ modification, a signal that is less likely to manifest in carbonate-dominated systems (which can be $\delta^{18} \mathrm{O}$ buffered).

Seven concretions of the Miocene Monterey Formation and the Upper Cretaceous Holz Shale were analyzed for their clumped-isotope composition to calculate precipitation temperatures. These two formations were selected because of their differing age, depositional environment, lithology, and potentially distinct (from each other) diagenetic histories. Analysis of concretions from two characteristically unique hosts provides a way to assess the applicability of the clumped-isotope proxy in concretions. The results demonstrate that temperatures derived from clumped-isotope thermometry can deviate markedly from those calculated using conventional $\delta^{18} \mathrm{O}$ thermometry with assumed pore-water compositions of $0 \%$, the approximate value of contemporaneous seawater $\delta^{18} \mathrm{O}$. The discrepancy between the two approaches can be attributed to the errors that arise when the pore-water composition is estimated using oversimplified and therefore inaccurate assumptions. Data show that independently determined temperatures provide the potential to track pore-water processes that perturb $\delta^{18} \mathrm{O}_{\text {fluid }}$ and better characterize diagenetic carbonate-forming environments.

\section{GEOLOGIC CONTEXT}

\section{The Monterey Formation}

The Miocene Monterey Formation is a hemipelagic, organic-rich and largely siliceous deposit that crops out along much of the California coast (see Fig. 1 for study site locations) (Bramlette 1946; Isaacs 1981; Schwalbach and Bohacs 1991; Behl and Garrison 1994). The large depositional area of the Monterey Formation during the Miocene led to the development of highly variable depocenters which have been interpreted to range from gradual slopes and sediment-starved plains (Isaacs 2001) to border-land basin type (e.g., Blake 1981) systems. Among these differing depositional environments, the Monterey Formation exhibits characteristics consistent with anoxic bottom waters, including laminated sediments, a general lack of bioturbation, the scarcity of benthic macrofossils, and relatively high organic contents (e.g., Isaacs 2001). Of course the differences in depositional environment and its temporal variation have produced both spatial and stratigraphic heterogeneity in the Monterey Formation, and as a result potentially have led to differences in post depositional processes across Monterey facies.

The Monterey Formation contains evidence of a diverse diagenetic history-involving phosphate-mineral genesis (e.g., Garrison et al. 1987; Föllmi et al. 2005), silica polymorphism (e.g., Behl and Garrison 1994), organic-matter degradation and/or preservation (e.g., John et al. 2002; Loyd et al. 2012), and concretion precipitation (e.g., Bramlette 1946; Kushnir and Kastner 1984; Hennessy and Knauth 1985) - aspects of which probably were driven by or led to its high organic content (up to $25 \%$ by weight; Isaacs 2001). Because of this high organic content, the Monterey Formation is an important source and reservoir rock for petroleum in California (Surdam and Stanley 1981; Mertz et al. 1983; Isaacs 1981).

Carbonate concretions and cemented layers are abundant in the Monterey Formation (Figs. 2, 3) (Kushnir and Kastner 1984; Hennessy and Knauth 1985; Burns and Baker 1987; Loyd et al. 2012). These concretions are generally cement-rich $(\sim 80 \%$ dolomite and/or calcite, by 

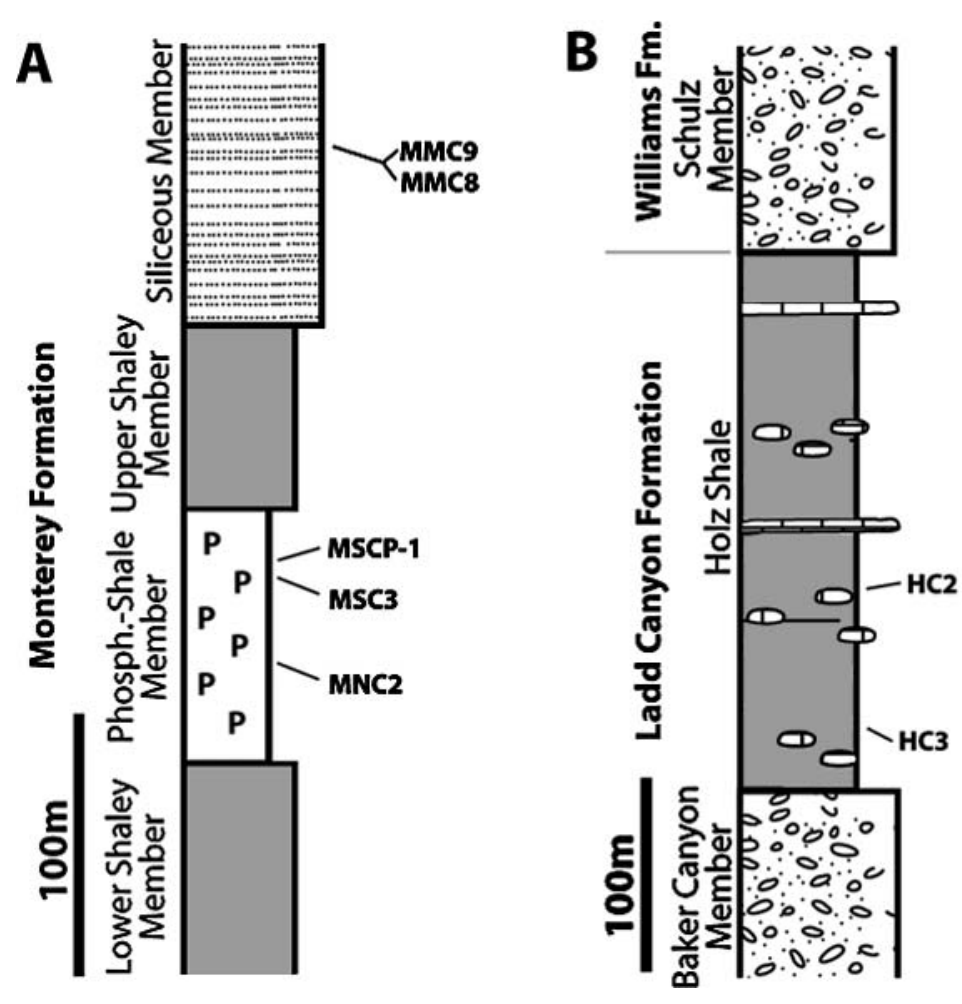

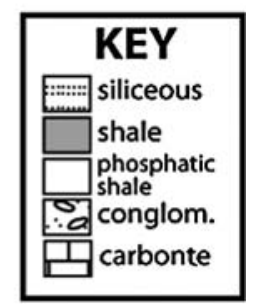

FIG. 2.-Generalized stratigraphic columns of A) the Monterey Formation and B) the Holz Shale. The horizons of sampled concretions are indicated. volume) and contain relatively little depositional carbonate $(<5 \%$ by volume, see Fig. 2) (Loyd et al. 2012). Carbon and oxygen isotope variation among individual concretions has been well documented from the Monterey Formation, and concretion formation temperatures have been inferred based on conventional carbonate-water oxygen isotope thermometry, using measured $\delta^{18} \mathrm{O}_{\text {carb }}$ values and assumed $\delta^{18} \mathrm{O}_{\mathrm{pw}}$ values (Kushnir and Kastner 1984; Hennessy and Knauth 1985; Burns and Baker 1987).

\section{The Holz Shale}

The Upper Cretaceous Holz Shale is organic-rich, fossiliferous and crops out in the Santa Ana Mountains of southern California (Fig. 1) (Schoellhamer et al. 1954; Buck and Bottjer 1985). As the upper member of the Ladd Canyon Formation, the Holz Shale overlies the conglomerate-dominated Baker Canyon Member and underlies the Williams Formation (Fig. 2; Packard 1916). The Holz Shale has been interpreted as a marine slope deposit (Buck and Bottjer 1985) based largely on the presence of fossils of the thin-shelled bivalve Inoceramus, an assemblage of agglutinated foraminifera, the trace fossils Thalassinoides and Ophiomorpha, the common occurrence of conglomeratic debris flows, chute and gully deposits, and turbidites (Buck and Bottjer 1985). As with the Monterey Formation, the Holz Shale exhibits many characteristics consistent with deposition under anoxic conditions, including laminated sediments and a paucity of bioturbation.

Although interpreted as a slope deposit, Buck and Bottjer (1985) conclude that the Holz Shale was deposited very near the paleo-shoreline, outboard of a relatively narrow shelf. The presence of terrestrial plant debris in the unit is consistent with a near-shore depocenter. Concretions of the Holz Shale occur as white calcite concretions (from $\sim 5$ to $100 \mathrm{~cm}$ in diameter) and cemented layers (Fig. 4). Some concretions contain vertically aligned (orthogonal to host bedding) septarian veins and rare bivalve tests (the concretions analyzed here contained insignificant detrital carbonate). Cement contents in concretions are relatively high ( $>60 \%$ by volume). There are currently no published isotopic data from Holz Shale concretions.

\section{METHODS}

Seven concretions and concretionary layers were sampled from the Monterey Formation and the Holz Shale. Monterey samples consist of two concretionary layers (MSCP-1 and MSC3) and three nodular to irregular concretions (MMC8-RB, MMC9-M, and MNC2). Concretion MNC2 is calcite whereas all other Monterey concretions are dolomite (Loyd et al. 2012). Holz Shale samples consist of two calcite concretions ( $\mathrm{HC} 2$ and $\mathrm{HC} 3$ ). To ensure sampling of the most representative regions of concretions and check for crystallographic and chemical zonation, thin

FIG. 3.-Images of Monterey Formation concretions. A) MNC2, B) MSCP-1, C) MSC3, D) MMC8, and E) MMC9. Numbers correspond to 1 = field photograph, $2=$ transmitted-light photomicrograph, and 3 = backscattered-electron photomicrograph. Sampled regions of each concretion (in A1, B1, etc.) are outlined by dashed lines and labeled where multiples occur. Notice the relatively uniform texture, tone, and crystal habit in photomicrograph and backscattered-images. The transmittedlight photomicrographs demonstrate the fine-crystalline habit exhibited by the Monterey concretions. These images also show various depositional components, including microfossils and very fine material (potentially clays). Backscattered-electron image B3 exhibits some minor zonation, with the less abundant, light-colored phase occupying 16\% of the photomicrograph area. Circled regions in A2 correspond to foraminifera tests which make up $<5 \%$ of the thin-section area. Black regions in all of the backscattered-electron images and the gray regions in C3 and E3 correspond to surface relief and not crystallographic zonation. In addition, white objects in B3, C3, and E3 are pyrite crystals arranged in intact and/or fragmented framboids. 

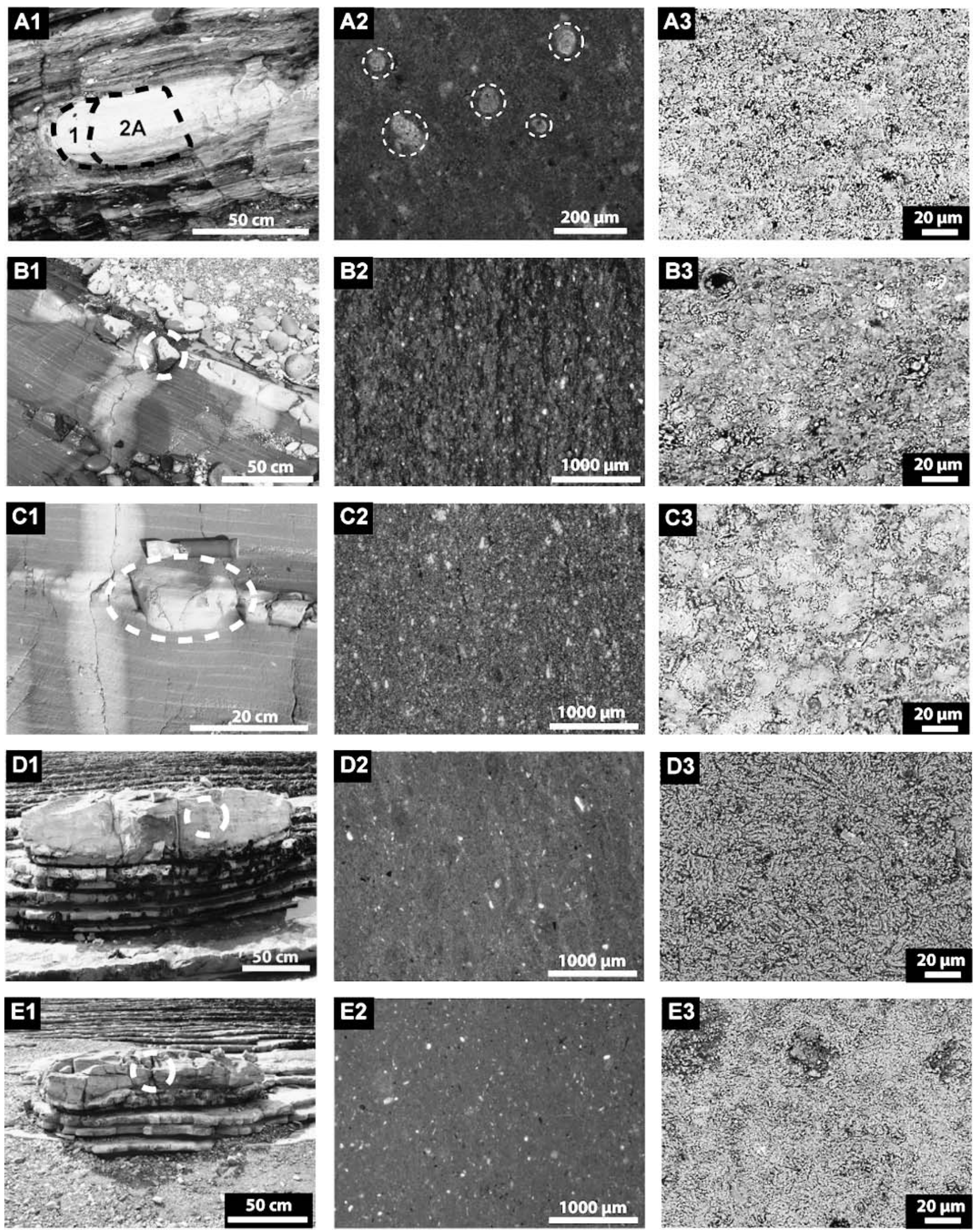

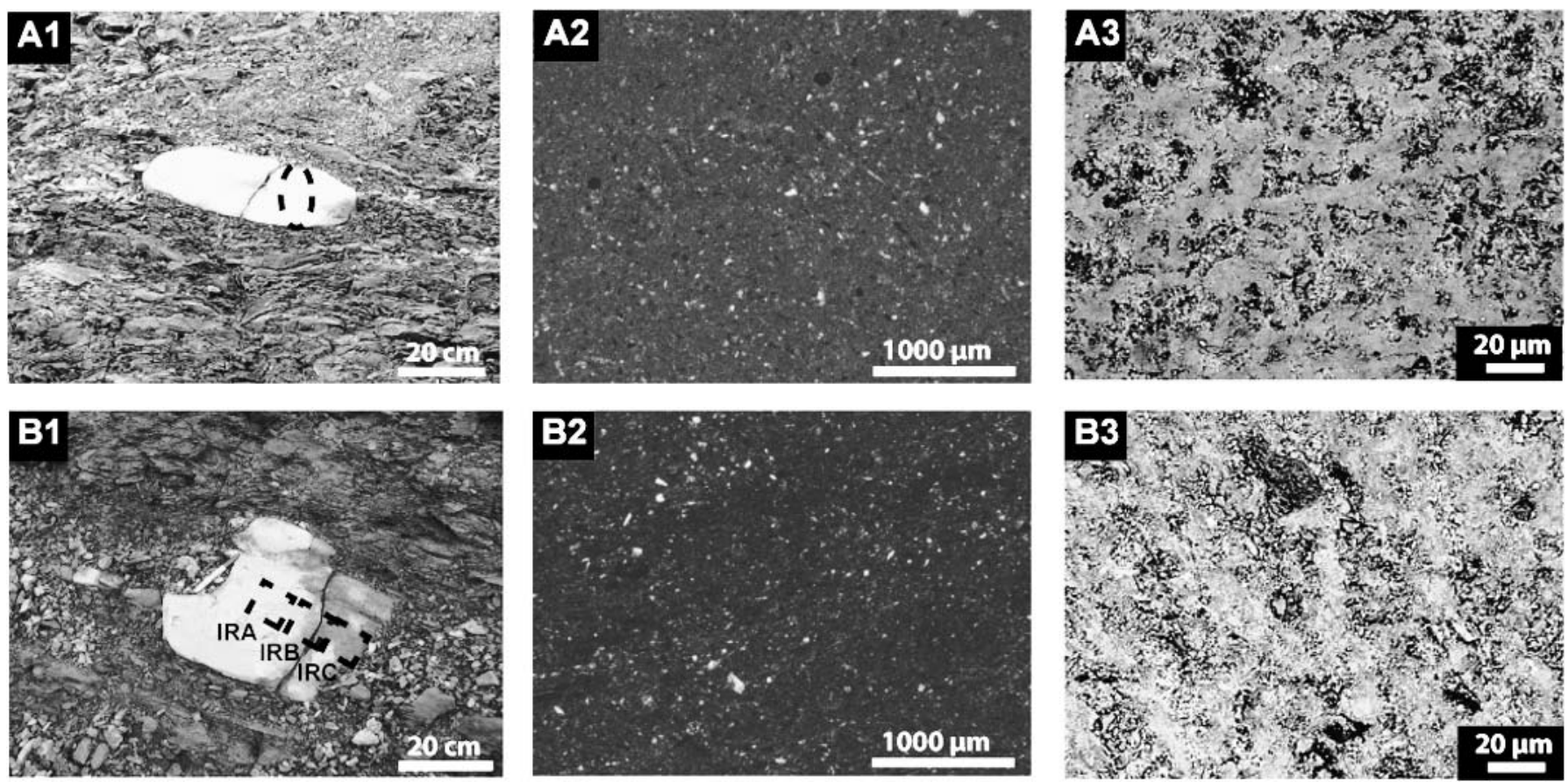

FIG. 4.- Images of Holz Shale concretions. A) HC2 and B) HC3. Numbers are the same as in Figure 2. As in the Monterey samples, Holz Shale concretions exhibit a fine-grained and relatively homogeneous crystallographic appearance. Transmitted-light photomicrographs demonstrate this fine-crystalline texture and display various depositional components, including unidentified, fine opaque grains (clays?) and some angular siliciclastic grains. The backscatter images reveal no obvious zonation. Black regions in A3 and B3 correspond to surface relief and not crystallographic zonation. As in the backscattered-electron images of Figure 3, white objects are framboidal pyrite crystals.

sections were examined via a petrographic microscope, a cathodoluminescence microscope, and a LEO 1430VP scanning electron microscope with backscatter imaging capability. Subsequent geochemical (see below) analyses were conducted on bulk powders generated from the most homogeneous regions (identified in hand sample and microscopically) of each concretion.

Concretion samples were analyzed for $\delta^{18} \mathrm{O}_{\text {carb }}, \delta^{13} \mathrm{C}_{\text {carb }}$, and $\Delta_{47}$. Nodular concretions $\mathrm{MNC} 2$ and $\mathrm{HC} 3$ were sampled in multiple locations to explore spatial variation within individual concretions (data shown in Table 1). Values of $\Delta_{47}$ were determined by calculating $\delta^{18} \mathrm{O}, \delta^{13} \mathrm{C}$, and the abundance of mass- 47 isotopologues (after Ghosh et al. 2006; Tripati et al. 2010). Given potentially high organic content, samples were pretreated with cold hydrogen peroxide and subjected to a series of distilledwater rinses before being dried in an oven at $50^{\circ} \mathrm{C}$. Treated samples were digested in phosphoric acid and the resultant $\mathrm{CO}_{2}$ analyzed for masses 4449 on a Thermo Electron Finnigan MAT 253 gas source isotope ratio mass spectrometer at the California Institute of Technology. Measurements of the mass-48 isotopologue were conducted to screen for potential organic contamination of the mass- 47 signal (see Appendix for $\delta_{48}$ data). This spectrum of masses along with known fractionation factors for ${ }^{18} \mathrm{O} /{ }^{16} \mathrm{O}$ and ${ }^{13} \mathrm{C} /{ }^{12} \mathrm{C}$ allows quantification of carbonate $\delta^{18} \mathrm{O}, \delta^{13} \mathrm{C}$, and $\Delta_{47}$ values (Ghosh et al. 2006; Huntington et al. 2009; Eagle et al. 2010; Passey et al. 2010; Tripati et al. 2010; and Eiler 2011). Values of $\Delta_{47}$ are reported as the \%o difference relative to a stochastic distribution of isotopologues. The $\Delta_{47} \pm$ values correspond to one standard error (1 s.e.) (Table 1). $\delta^{13} \mathrm{C}$ and $\delta^{18} \mathrm{O}$ are reported in \%o relative to the VPDB and both the VSMOW and VPDB standards, respectively. Average reproducibility of standard and sample $\Delta_{47}$ values is $\pm 0.009 \%$, and the reproducibilities of $\delta^{13} \mathrm{C}$ and $\delta^{18} \mathrm{O}$ are both better than $\pm 0.008 \%$. The data reported here are not cast into the universal reference frame (URF) of Dennis et al. (2011); however the corrected data do not differ significantly from the data presented here (see Appendix).

\section{CONCRETION MINERALOGY AND PETROGRAPHY}

The concretions of the Monterey Formation analyzed here are dolomite, with one exception (concretion MNC2 is calcite). Mineralogy was determined by Loyd et al. (2012) via ICP-MS and confirmed by Xray diffraction. The Holz Shale concretions are composed of calcite as proposed by Buck and Bottjer (1985) and confirmed by thin-section staining with Alizarin Red S.

Petrographically, all concretions exhibit a relatively fine-crystalline texture with individual carbonate crystal diameters dominantly less than $5 \mu \mathrm{m}$ and rare occurrences of crystals up to $\sim 20 \mu \mathrm{m}$ across (Figs. 3, 4). The crystals are arranged in an interlocking mosaic and are mostly anhedral with the exception of a few euhedral rhombs that occur exclusively within the dolomite concretions of the Monterey Formation. As expected in diagenetic precipitates, these concretions contain various depositional and earlier diagenetic components. Monterey Formation concretions contain diatom frustrules, rare foraminifera, and phosphate nodules. The Holz Shale concretions contain locally abundant angular siliciclastic grains. Both Monterey and Holz Shale concretions contain pyrite, opaque grains, and very fine-grained material (presumably clays).

Cathodoluminescence microscopy revealed variable luminescence characteristics among samples (Table 1). In individual samples, however, luminescence is quite uniform. Backscattered-electron imaging largely confirmed a general lack of zonation, with one exception. The Shell Beach concretion, MSCP-1, of the Monterey Formation exhibits subtle crystallographic zonation (Figs. 3, 5). Ultimately, this concretion is dominated by a single phase of cement (the electron dark phase) that makes up $\sim 84 \%$ of the photomicrograph area as calculated by image analysis. It should be noted that the backscattered-electron images in Figures 3 and 4 display some color variability that is not associated with zonation. In particular, black and darker gray regions in some images reflect the surface relief of the sample and not crystallographic zonation. 
See the associated figure captions for details. Aside from the single example discussed above, significant zonation was not recognized in any sample despite examination at multiple magnifications.

\section{CONCRETION GEOCHEMISTRY AND PRECIPITATION TEMPERATURES}

Geochemical data vary within and among samples (Table 1). Concretions of the Monterey Formation display $\Delta_{47}$ values that range from $0.612 \pm 0.013$ to $0.685 \pm 0.006$. Holz Shale samples exhibit $\Delta_{47}$ values ranging from $0.565 \pm 0.007$ to $0.611 \pm 0.012$. Concretions of the Monterey Formation exhibit $\delta^{13} \mathrm{C}_{\text {carb }}$ values that range from -12.7 to $+15.0 \%$ (VPDB) and $\delta^{18} \mathrm{O}_{\text {carb }}$ values that range from -0.5 to $+1.5 \%$ VPDB (or +30.4 to $+32.5 \%$ VSMOW). Calcite concretions of the $\mathrm{Holz}$ Shale yield $\delta^{13} \mathrm{C}_{\text {carb }}$ values from -3.4 to $-9.1 \%$ and $\delta^{18} \mathrm{O}_{\text {carb }}$ values between -9.7 to $-6.9 \%$ VPDB (+20.9 to $+23.8 \%$ VSMOW).

These $\Delta_{47}$ values correspond to formation temperatures of $\sim 17$ to $35^{\circ} \mathrm{C}$ and $\sim 33$ to $44^{\circ} \mathrm{C}$ for concretions of the Monterey Formation and Holz Shale, respectively, as determined using the calibration of Ghosh et al. (2006). Theoretical calculations suggest that cation substitution (i.e., calcite versus dolomite) have minimal effects on $\Delta_{47}$ values (Schauble et al. 2006; Guo et al. 2009; Eagle et al. 2010), consistent with observations of calibration materials.

\section{DISCUSSION}

\section{Discrepancy in Concretion Precipitation Temperature}

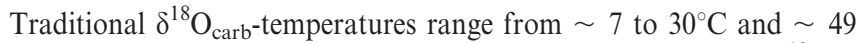
to $66^{\circ} \mathrm{C}$ for Monterey and Holz Shale concretions, respectively $\left(\delta^{18} \mathrm{O}_{\mathrm{pw}}\right.$ assigned the value of $0 \%$, see above). In all but one sample, $\Delta_{47^{-}}$ temperatures differ markedly from these values (Fig. 6A; Table 1). Analysis of Holz Shale samples produced the most divergent precipitation temperatures between approaches. In the most extreme case (HC3-IRB), the temperature difference is more than $\sim 29^{\circ} \mathrm{C}$, with the clumpedisotope data yielding lower temperatures. The remaining samples from concretion $\mathrm{HC} 3$ also exhibit clumped-isotope temperatures that are more than $22^{\circ} \mathrm{C}$ below traditional oxygen isotope-based estimates. In all but one Monterey concretion, $\Delta_{47}$ temperatures are higher than those calculated by oxygen isotope thermometry, with a maximum difference of $\sim 12^{\circ} \mathrm{C}$.

\section{Assessing Later Diagenetic Resetting and Concretion Cementation Styles}

Concretions exhibiting laminae deflection and relatively high cement content (like those analyzed here) likely precipitated at shallow depths. The concretions may have undergone subsequent partial recrystallization at depth, resulting in the resetting of geochemical signatures to higher temperatures and lower $\delta^{18} \mathrm{O}_{\text {carb }}$ and, potentially, zoned cements. For the most part, petrographic examination reveals little crystallographic zonation. One sample exhibits some zonation under backscatter (Fig. 3 panel C3); however this sample is clearly dominated by a single phase ( $\sim 84 \%$ of the photomicrograph area; Fig. 5 ). Therefore, while zonation does occur, it is not common and the sample that does exhibit zoning is dominated by a single cement phase.

Although we find only minor evidence for multiple generations of cement (aside from sparse septarian veins in Holz Shale samples; see above), certain concretions (other than those analyzed here) apparently form in a complex pervasive manner, in which early and late cement generations precipitate throughout the concretion body (Mozley 1996; Raiswell and Fisher 2000). It has been proposed that only minimal amounts of initial cement are required to produce a rigid structure capable of withstanding subsequent compaction (e.g., Spinelli et al. 2007; White et al. 2011). As a result, incompletely cemented concretions can contain abundant residual pore space despite burial. Later cements can 

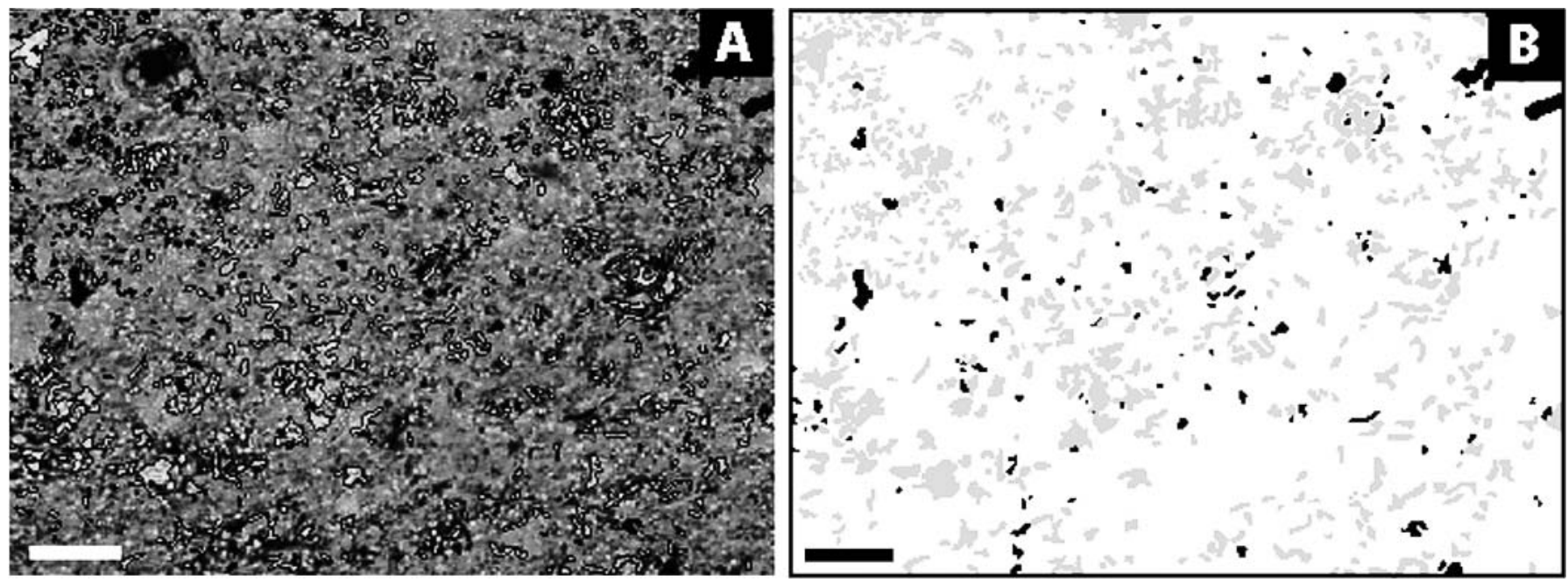

FIG. 5.-Distribution of electron-light phase in MSCP-1. A) Backscatter image with the electron-light phase traced and B) sketch of the distribution of the electronlight phase (gray) and white phase, likely pyrite (black). The light phase occupies $\sim 16 \%$ of the photomicrograph area. Scale bars correspond to $20 \mu \mathrm{m}$.

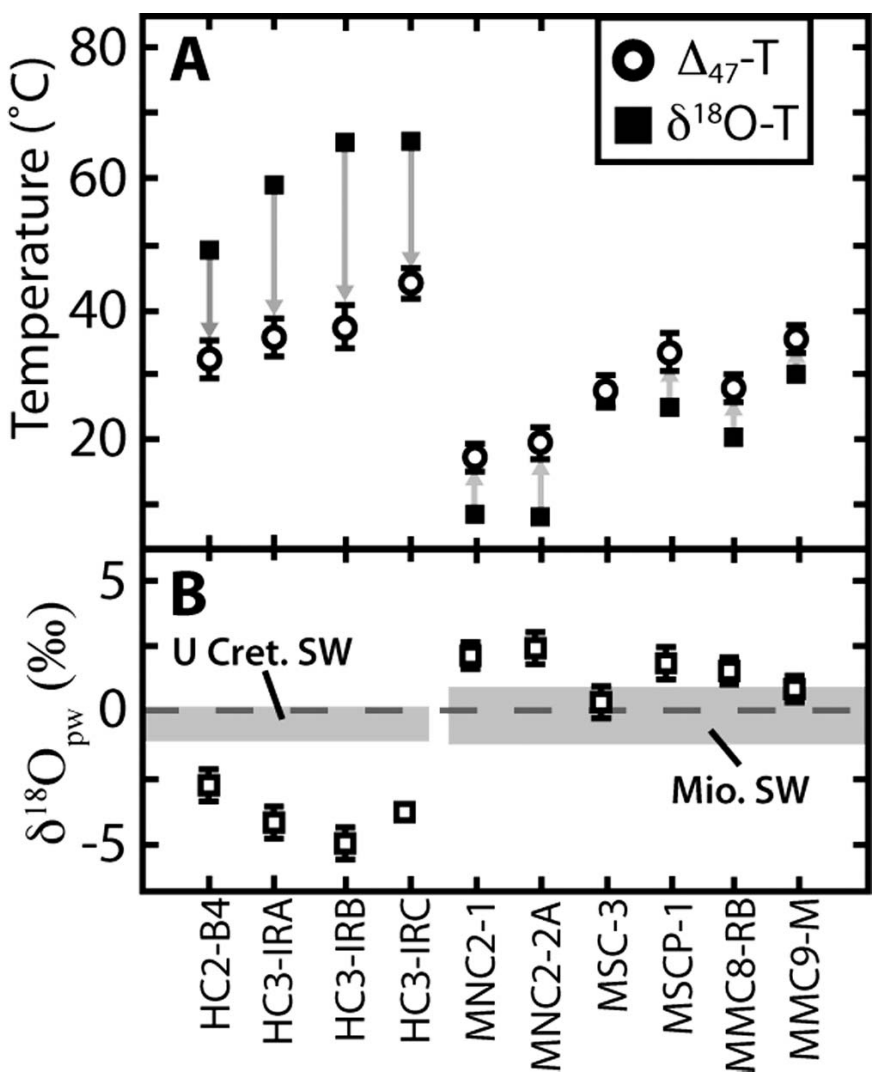

FIG. 6.-Diagram showing A) concretion precipitation temperatures (T) calculated using both $\delta^{18} \mathrm{O}_{\text {carb }}$ and $\Delta_{47}$ thermometry and $\mathbf{B}$ ) calculated $\delta^{18} \mathrm{O}_{\mathrm{pw}}$ values and contemporaneous seawater $(\mathrm{SW}) \delta^{18} \mathrm{O}$ values for the ages of the respective host unit (Veizer et al. 1999; Leer et al. 2000; Shevenell et al. 2008). Generally, $\delta^{18} \mathrm{O}_{\mathrm{pw}}$ values do not fall within the associated seawater envelope, likely reflecting that diagenetic processes affected $\delta^{18} \mathrm{O}_{\mathrm{pw}}$ values. Error bars correspond to 1 s.e. then fill in the remaining pore space. Raiswell and Fisher (2000) and Klein et al. (1999) have suggested that such combinations of early-stage and late-stage cements may account for the anomalously low $\delta^{18} \mathrm{O}_{\text {carb }}$ values in some concretions. This pervasive style of precipitation would undoubtedly complicate specific geochemical interpretations, particularly if cement generations cannot be identified (petrographically, for example) and isolated for analyses.

Ultimately, the imaging techniques used here (traditional transmittedlight microscopy, cathodoluminescence microscopy, and backscatteredelectron imaging) reveal only minor crystallographic zonation in the one of the concretions. However, the potential for cryptic, unrecognizable zonation remains, and therefore the following discussion includes broad interpretations regarding geochemical data generated from analysis of bulk powders, without drawing interpretations from specific absolute values. The data are considered in relation to the traditional temperature calculation (hotter versus colder for clumped-isotope temperatures) or to the predicted contemporaneous seawater $\delta^{18} \mathrm{O}$ values.

\section{Pore Water $\delta^{18} O$ Values}

One explanation for the differences between carbonate clumpedisotope thermometry and conventional carbonate-water oxygen isotope thermometry is that pore fluids differed in $\delta^{18} \mathrm{O}$ from modern mean seawater values. The variability of seawater $\delta^{18} \mathrm{O}$ has been determined for the Miocene (Leer et al. 2000; Shevenell et al. 2008) and the Upper Cretaceous (Veizer et al. 1999), and exhibits a narrow range centered on a value of $0 \%$ (see shaded regions in Fig. 6B). The initial assumption that $\delta^{18} \mathrm{O}_{\mathrm{pw}}=$ seawater $\delta^{18} \mathrm{O}(=0 \%)$ is warranted only if the concretion precipitates in marine sediments where $\delta^{18} \mathrm{O}_{\mathrm{pw}}$ is not highly modified from seawater $\delta^{18} \mathrm{O}$. In general, the presence of shallow precipitation indicators (e.g., external lamina deflection) is used to argue a nearseawater value. However, as is evident from the data, even concretions exhibiting features suggesting shallow formation may have formed in sediments with significantly modified $\delta^{18} \mathrm{O}_{\mathrm{pw}}$.

Several mechanisms can produce modified $\delta^{18} \mathrm{O}_{\mathrm{pw}}$ (i.e., $\delta^{18} \mathrm{O}_{\mathrm{pw}} \neq$ seawater $\delta^{18} \mathrm{O}$ ) during diagenesis in sediments (Table 2). For example, an influx of meteoric fluid would result in ${ }^{18} \mathrm{O}$-depleted pore waters (Lohmann 1988), as would the formation of gas hydrate (where ${ }^{18} \mathrm{O}$ is preferentially incorporated in the hydrate lattice; Perry et al. 1976), shale hyperfiltration (Marshall 1982), organic carbon-coupled sulfate reduction (Sass et al. 1991), or the precipitation of carbonate (unlikely because 
TABLE 2.-Pore-water $\delta^{18} \mathrm{O}$ modifying diagenetic processes.

\begin{tabular}{|c|c|c|}
\hline Process & $\begin{array}{l}\text { Relative Change } \\
\text { in } \delta^{18} \mathrm{O}_{\mathrm{pw}}\end{array}$ & References \\
\hline Clay dewatering & + & $\begin{array}{l}\text { Clayton et al, 1966; Hitchon and } \\
\text { Friedman } 1969\end{array}$ \\
\hline Silica diagenesis & + & $\begin{array}{l}\text { Morton and Land 1987; Behl and } \\
\text { Garrison } 1994\end{array}$ \\
\hline Carbonate dissolution & + & $\begin{array}{l}\text { Clayton et al. 1966; Hitchon and } \\
\text { Friedman } 1969\end{array}$ \\
\hline Gas-hydrate dissolution & + & $\begin{array}{l}\text { Perry et al. 1976; Hesse and Harisson } \\
\text { 1981; Bohrmann et al. } 1998\end{array}$ \\
\hline Influx of brine fluids & + & Morton and Land 1987 \\
\hline Carbonate formation & - & $\begin{array}{l}\text { Clayton et al. 1966; Hitchon and } \\
\text { Friedman } 1969\end{array}$ \\
\hline Gas-hydrate formation & - & $\begin{array}{l}\text { Perry et al. 1976; Hesse and Harrison } \\
\text { 1981; Bohrmann et al. } 1998\end{array}$ \\
\hline Volcanic ash alteration & - & $\begin{array}{l}\text { Lawrence et al. 1979; Pirrie and } \\
\text { Marshall } 1991\end{array}$ \\
\hline Basaltic alteration & - & $\begin{array}{l}\text { Lawrence and Gieskes 1981; Lawrence } \\
\text { and Taviani } 1988\end{array}$ \\
\hline Shale hyperfiltration & - & Marshall 1982 \\
\hline $\begin{array}{l}\text { Organic C-coupled } \\
\text { sulfate reduction }\end{array}$ & - & Sass et al. 1991 \\
\hline Influx of meteoric fluids & - & $\begin{array}{l}\text { Gross 1964; Allan and Mathews 1982; } \\
\text { Lohmann } 1988\end{array}$ \\
\hline
\end{tabular}

of mass-balance issues and precipitation-rate limitations; Burns 1998). In addition, the alteration of basaltic material (Lawrence and Gieskes 1981; Lawrence and Taviani 1988) and volcanic ash (Lawrence et al. 1979; Pirrie and Marshall 1991) would decrease $\delta^{18} \mathrm{O}_{\mathrm{pw}}$. Pore waters experiencing clay dewatering, opaline-silica diagenesis, hydrate dissolution, or carbonate dissolution would become enriched in ${ }^{18} \mathrm{O}$ versus coeval seawater (Clayton et al. 1966; Perry et al. 1976; Morton and Land 1987). Influx of evaporative brines enriched in ${ }^{18} \mathrm{O}$ would also influence ambient pore waters (Gross 1964; Allan and Mathews 1982; Lohmann 1988). Many of these processes occur in marine basins, and are relevant for interpreting $\delta^{18} \mathrm{O}_{\mathrm{pw}}$ values.

In this context, the concretions of the Monterey Formation exhibit $\delta^{18} \mathrm{O}_{\mathrm{pw}}$ values that extend from that proposed for coeval seawater (Shevenell et al. 2008) to those that are ${ }^{18} \mathrm{O}$-enriched (Fig. 6B). Whereas multiple processes can generate elevated oxygen isotope compositions in pore water, silica diagenesis is most likely to have impacted $\delta^{18} \mathrm{O}_{\mathrm{pw}}$ in the sediments of the Monterey Formation. The largely temperature-induced polymorphic phase transitions from Opal A to Opal CT to chert include a progressive reduction in the amount of lattice-bound water. Opal-bound water tends to be enriched in ${ }^{18} \mathrm{O}$ compared to contemporaneous seawater, and therefore upon polymorphism pore waters can experience isotopic enrichment (Behl and Garrison 1994). The Monterey Formation contains a wide range of silica polymorphs (including opal A, opal CT, and chert), reflective of pervasive silica diagenesis (Murata and Nakata 1974; Behl and Garrison 1994, Behl 1998). Interestingly, Baker and Kastner (1981) found that the transition from opal CT to quartz is likely to promote dolomite formation, suggesting a potential causative link between dolomite concretion precipitation and silica diagenesis. However, the range in precipitation temperatures (from $\sim 17$ to $35^{\circ} \mathrm{C}$ ) is probably too low to reflect formation in sediments experiencing the transition from Opal CT to quartz, which generally occurs at temperatures of $\sim 65$ to $80^{\circ} \mathrm{C}$, although in diatomite cherts with less than $10 \mathrm{wt} . \%$ detritus the conversion can occur at much lower temperatures $\left(\sim 30-40^{\circ} \mathrm{C}\right.$; Behl and Garrison 1994; Behl 2010). Therefore, we surmise that the elevated $\delta^{18} \mathrm{O}_{\mathrm{pw}}$ values reflect the relatively shallow polymorphic transition of Opal A to Opal CT, but we cannot completely rule out a potential contribution from the later conversion of Opal CT to quartz. Regardless of the specific polymorphic transformations, these data indicate that concretion authigenesis occurred either during or after silica diagenesis in sediments of the Monterey Formation.

Whereas the Monterey Formation contains variable amounts of clay minerals that, upon burial-driven dewatering and diagenesis, can yield elevated $\delta^{18} \mathrm{O}_{\mathrm{pw}}$ (Clayton et al. 1966), the low temperatures of concretion formation indicate precipitation well before the onset of marked clay reordering $\left(\sim 100^{\circ} \mathrm{C}\right.$, e.g., Aoyagi and Kazama 2006). Thus, silica diagenesis is the most probable cause of the pore-water ${ }^{18} \mathrm{O}$ enrichment.

Three of the four Holz Shale concretions exhibit $\delta^{18} \mathrm{O}_{\mathrm{pw}}$ values that lie well below the proposed seawater values for the glacier-free Upper Cretaceous (Leer et al. 2000). These isotopically depleted pore waters are probably the result of the influx of meteoric fluids, in agreement with the near-shore paleoenvironment (shore-proximal slope) proposed by Buck and Bottjer (1985). Gas hydrate accumulation can be ruled out because at temperatures of $\sim 40^{\circ} \mathrm{C}$ (Holz concretion formation temperatures) hydrate precipitation should not occur.

The $\delta^{18} \mathrm{O}_{\mathrm{pw}}$-modifying processes interpreted here (Monterey Formation - silica diagenesis; and Holz Shale - meteoric influx) were proposed by Mozley and Burns (1993) nearly twenty years ago as potential influences, but the means to decipher ancient pore-water isotope composition were not available. Whereas these two processes are reasonably attributable to the data in this study, the extension of these interpretations to alternate concretion-hosting localities is not warranted. Indeed, each concretion-hosting unit must be explored independently (preferably including clumped-isotope investigation) in consideration of its own lithologic and depositional-environment criteria. Ultimately, clumped-isotope analyses can provide new information concerning apparently anomalous concretion $\delta^{18} \mathrm{O}$ values and help resolve the relative importance of temperature versus pore-water composition on the inherited isotopic signal.

\section{Carbon Isotope Compositions and Other Biogeochemical Indicators}

As is typical of carbonate concretions (e.g., Mozley and Burns 1993), the $\delta^{13} \mathrm{C}_{\text {carb }}$ values of the Monterey and Holz Shale diagenetic carbonates exhibit wide variability both within individual samples and among samples. The carbon isotope compositions of the Holz Shale concretions range from -3.4 to $-9.1 \%$, consistent with a significant contribution from organic-matter carbon. Many reactions that degrade organic carbon in marine sediments are microbially driven and the Holz Shale precipitation temperatures are well within those amenable to biologic activity (e.g., Kashefi and Lovley 2003). Indeed the formation temperatures exhibited by both the Holz and Monterey concretions are below those at which the abiotic, thermal breakdown of organic matter occurs (Cornford 1990). Previous work on Monterey Formation concretions (including those analyzed here) has led to more specific interpretations regarding the biogeochemical processes responsible for authigenesis (Loyd et al. 2012). Loyd et al. (2012) concluded that concretions of Naples Beach (MNC2), Shell Beach (MSCP-1 and MSC3), and Montaña de Oro (MMC8 and MMC9) formed predominantly via iron and/or nitrate reduction, sulfate reduction, and methanogenesis, respectively. The precipitation temperatures of the $\mathrm{MNC} 2$ concretion are lower that those of Shell Beach and Montaña de Oro concretions, consistent with the more shallow depths of the nitrate and iron reduction zones compared to those of sulfate reduction and methanogenesis (Claypool and Kaplan 1974). However, it is important to note that the depth ranges of these organic-matter-degradation horizons can vary for a number of reasons, including organic content, depositional environment, and sedimentation rate, and therefore comparisons among concretions of differing sample locales may be unwarranted. Nevertheless, it is encouraging that the reported concretion precipitation temperatures are well within the limits of biologic activity and consistent with previous work. 


\section{SUMMARY}

Carbonate concretions of the Miocene Monterey Formation and the Upper Cretaceous Holz Shale analyzed using clumped-isotope thermometry yield temperatures of precipitation that range from $\sim 17$ to 35 and $\sim 33$ to $44^{\circ} \mathrm{C}$, respectively. Nine out of ten samples exhibit substantially different temperatures of precipitation when compared to the traditional $\delta^{18} \mathrm{O}_{\text {carb }}$-temperature proxy (likely reflecting nonzero $\delta^{18} \mathrm{O}_{\mathrm{pw}}$ values). Modern marine pore waters can be influenced by many diagenetic processes that perturb $\delta^{18} \mathrm{O}$ values from the initial seawater composition, including an influx of nonmarine fluids (meteoric or brine fluids), hydrate and carbonate formation or dissolution, and clay or silica diagenesis Seawater $\delta^{18} \mathrm{O}$ is variable over geologic timescales, but previously predicted ranges of seawater variability do not reasonably account for the magnitude of variability observed here. Ultimately, the signals recorded in the concretions of the Monterey Formation and the Holz Shale likely reflect the postdepositional influence of silica diagenesis and meteoric-fluid influx, respectively, conclusions that would have eluded detection without the application of the new clumped-isotope paleothermometer.

\section{ACKNOWLEDGMENTS}

The authors would like to thank Rob Eagle, David Bottjer, Will Berelson, and Jon Schwalbach for insightful scientific discussion. Reviews and input by Cedric John, Associate Editor Peter Mozley, and Editor Gene Rankey helped significantly strengthen the final manuscript. This research was supported by the Agouron Institute, the American Chemical Society's Petroleum Research Fund (grant \# 51182-DNI2) and the National Science Foundation (EAR grant \# 0949191) through awards to A.T. and S.L.

\section{REFERENCES}

Allan, J.R., AND Mathews, R.K., 1982, Isotope signatures associated with early meteoric diagenesis: Sedimentology, v. 29, p. 797-817.

Aoyagi, K., AND KazAma, T., 2006, Transformational changes of clay minerals, zeolites and silica minerals during diagenesis: Sedimentology, v. 27, p. 179-188.

Astin, T.R., And Scotchman, L.C., 1988, The diagenetic history of some septarian concretions from the Kimmeridge Clay, England: Sedimentology, v. 35, p. 349-368.

BaKer, P.A., AND Kastner, M., 1981, Constraints on the formation of sedimentary dolomite: Science, v. 213, p. 214-216.

BeHL, R.J., 1998, Relationships between silica diagenesis, deformation, and fluid flow in Monterey Formation cherts, Santa Maria Basin, California, in Eichubl, P., ed. Diagenesis, Deformation, and Fluid Flow in the Miocene Monterey Formation: SEPM, Pacific Section, Special Publication 83, p. 77-83.

BeHL, R.J., 2010, Chert spheroids of the Monterey Formation, California (USA): earlydiagenetic structures of bedded siliceous deposits: Sedimentology, v. 58, p. 325-351.

Behl, R.J., AND Garrison, R.E., 1994, The origin of chert in the Monterey Formation of California (USA), in Iijima, I., Abed, A., and Garrison, R., eds., Siliceous, Phosphatic and Glauconitic Sediments of the Tertiary and Mesozoic: Utrecht, 29th International Geological Congress, Proceedings, Part C, p. 101-132.

BlaKe, G.H., 1981, Biostratigraphic relationships of Neogene benthic foraminifera from the southern California outer continental borderland to the Monterey Formation, in Garrison, R.E., and Douglas, R.G., eds., The Monterey Formation and Related Siliceous Rocks of California: SEPM, Pacific Section, Book 15, p. 1-14.

Bohrmann, G., Greinert, J., Suess, E., and Torres, M., 1998, Authigenic carbonates from the Cascadia subduction zone and their relation to gas hydrate stability: Geology, v. 26, p. 647-650.

Bramlette, M.N., 1946, The Monterey Formation of California and the origins of its siliceous rocks: U.S. Geological Survey, Professional Paper 212, 57 p.

Buck, S.P., AND BotTJeR, D.J., 1985, Continental slope deposits from a Late Cretaceous, tectonically active margin, southern California: Journal of Sedimentary Petrology, v 55 , p. 843-855.

Burns, S.J., 1998, Can diagenetic precipitation of carbonate nodules affect pore-water oxygen isotope ratios?: Journal of Sedimentary Research, v. 68, p. 100-103.

Burns, S.J., AND BAKER, P.A., 1987, A geochemical study of dolomite in the Monterey Formation, California: Journal of Sedimentary Petrology, v. 57, p. 128-139.

Claypool, G.E., and Kaplan, I.R., 1974, The origin and distribution of methane in marine sediments, in Kaplan, I.R., ed., Natural Gases in Marine Sediments: New York, Plenum Press, p. 99-140.

Clayton, R.N., Friedman, I., Graf, D.L., Mayeda, T.K., Meents, W.F., and Shimp, N.F., 1966, The origin of saline formation waters, I. Isotopic composition: Journal of Geophysical Research, v. 71, p. 3869-3882.
Coleman, M.L., And Raiswell, R., 1981, Carbon, oxygen and sulphur isotope variation in carbonate concretions of the Upper Lias of NE England: Geochimica et Cosmochimica Acta, v. 45, p. 329-340.

Cornford, C., 1990, Source rocks and hydrocarbons of the North Sea, in Glennie, K.W., ed., Petroleum Geology of the North Sea, Basic Concepts and Recent Advances: Oxford, U.K., Blackwell Science, p. 376-462.

Dennis, K.J., Affek, H.P., Passey, B.H., Schrag, D.P., and Eiler, J.M., 2011, Defining an absolute reference frame for "clumped" isotope studies of $\mathrm{CO}_{2}$ : Geochimica et Cosmochimica Acta, v. 75, p. 7117-7131.

Dix, G.R., AND Mullins, H.T., 1987, Shallow, subsurface growth and burial alteration of middle Devonian calcite concretions: Journal of Sedimentary Petrology, v. 57, p. $140-152$.

Eagle, R.A., Schauble, E.A., Tripati, A., Tutken, T., Hulbert, C., and Eiler, J., 2010, Body temperatures of modern and extinct vertebrates from ${ }^{13} \mathrm{C}-{ }^{18} \mathrm{O}$ bonds abundances in bioapatite: National Academy of Sciences, Proceedings, v. 107, p 10377-10382.

EILER, J., 2007, "Clumped-isotope" geochemistry-the study of naturally-occurring, multiply-substituted isotopologues: Earth and Planetary Science Letters, v. 262, p. 309-327.

EILER, J.M., 2011, Paleoclimate reconstruction using carbonate clumped isotope thermometry: Quaternary Science Reviews, v. 30, p. 3575-3588.

Ferry, J.M., Passey, B.H., Vasconcelos, C., and Eiler, J.M., 2011, Formation of dolomite at $40-80{ }^{\circ} \mathrm{C}$ in the Latemar carbonate buildup, Dolomites, Italy, from clumped isotope thermometry: Geology, v. 39, p. 571-574.

Föllmi, K.B., Badertscher, C., de Kaenel, E., Stille, P., John, C.M., Adatte, T., and Steinmann, T., 2005, Phosphogenesis and organic-carbon preservation in the Miocene Monterey Formation at Naples Beach, California-the Monterey hypothesis revisited: Geological Society of America, Bulletin, v. 117, p. 589-619.

Garrison, R.E., Kastner, M., and Kolodny, Y., 1987, Phosphorites and phosphatic rocks in the Monterey Formation and related Miocene units, coastal California, in Ingersoll, R.V., and Ernst, W.G., eds., Cenozoic Basin Development in Coastal California: Rubey, Volume 6: Englewood Cliffs, New Jersey, Prentice-Hall, p. 348381.

Ghosh, P., Adkins, J., Affek, H., Balta, B., Guo, W., Schauble, E., Schrag, D., and EILER, J., 2006, ${ }^{13} \mathrm{C}-{ }^{18} \mathrm{O}$ bonds in carbonate minerals: a new kind of paleothermometer: Geochimica et Cosmochimica Acta, v. 70, p. 1439-1456.

Gross, M.G., 1964, Variations in the $\mathrm{O}^{18} / \mathrm{O}^{16}$ and $\mathrm{C}^{13} / \mathrm{C}^{12}$ ratios of diagenetically altered limestones in the Bermuda islands: Journal of Geology, v. 72, p. 170-194.

Guo, W.F., Mosenfelder, J.L., Goddard, W.A., and Eiler, J.M., 2009, Isotopic fractionations associated with phosphoric acid digestion of carbonate minerals: insights from first-principles theoretical modeling and clumped isotope measurements Geochimica et Cosmochimica Acta, v. 73, p. 7203-7225.

Hennessy, J., AND KnAuth, L.P., 1985, Isotopic variations in dolomite concretions from the Monterey Formation, California: Journal of Sedimentary Petrology, v. 55, p. 120 130.

Hesse, R., And Harrison, W.E., 1981, Gas hydrates (clathrates) causing pore-water freshening and oxygen isotope fractionation in deep-water sedimentary sections of terrigenous continental margins: Earth and Planetary Science Letters, v. 55, p. 453462.

Hitchon, B., AND Friedman, I., 1969, Geochemistry and origin of formation waters in the western Canada sedimentary basin-I. Stable isotopes of hydrogen and oxygen: Geochimica et Cosmochimica Acta, v. 33, p. 1321-1349.

Hudson, J.D., 1978, Concretions, isotopes and the diagenetic history of the Oxford Clay (Jurassic) of central England: Sedimentology, v. 25, p. 339-370.

Hudson, J.D., and Friedman, I., 1974, Carbon and oxygen isotopes in concretions: relationships to pore-water changes during diagenesis, in Cadek, J., and Paces, T., eds., Proceedings: Prague, Geological Survey, International Symposium on WaterRock Interaction, p. 331-339.

Huntington, K.W., Eiler, J.M., Affek, H.P., Guo, W., Boniface, M., Yeung, L.Y., Thiagarajan, N., Passey, B., Tripati, A., Daeron, M., and Came, R., 2009, Methods and limitations of "clumped" $\mathrm{CO}_{2}$ isotope $\left(\Delta_{47}\right)$ analysis by gas-source isotope ratio mass spectrometry: Journal of Mass Spectrometry, v. 44, p. 1318-1329.

Huntington, K.W., Budd, D.A., Wernicke, B.P., And Eiler, J.M., 2011, Use of clumped-isotope thermometry to constrain the crystallization temperature of diagenetic calcite: Journal of Sedimentary Research, v. 81, p. 656-669.

Irwin, H., Curtis, C., AND Coleman, M., 1977, Isotopic evidence for source of diagenetic carbonates formed during burial of organic-rich sediments: Nature, v. 27, p. $577-591$.

IsAACS, C.M., 1981, Field characterization of rocks in the Monterey Formation along the coast near Santa Barbara, California, in Isaacs, C.M., ed., Guide to the Monterey Formation in the California Coastal Area, Ventura to San Luis Obispo: American Association of Petroleum Geologists, Pacific Section, Special Publication 52, p. 39-53. IsAaCs, C.M., 2001, Depositional framework of the Monterey Formation, California, in Isaacs, C.M., and Rullkötter, J., eds., The Monterey Formation: from Rocks to Molecules: New York, Columba University Press, p. 1-30.

John, C.M., Föllmi, K.B., de Kaenel, E., Adatte, T., Steinmann, P., and BADERTSCHER, C., 2002, Carbonaceous and phosphate-rich sediments of the Miocene Monterey Formation at El Capitan State Beach, California, USA: Journal of Sedimentary Research, v. 72, p. 252-267.

Kashefi, K., and Lovley, D.R., 2003, Extending the upper temperature limit for life: Science, v. 301, p. 943. 
Kim, S.-T., AND O'NEIL, J.R., 1997, Equilibrium and nonequilibrium oxygen isotope effects in synthetic carbonates: Geochimica et Cosmochimica Acta, v. 61, p. 34613475 .

Klein, J.S., Mozley, P., Campbell, A., and Cole, R., 1999, Spatial distribution of carbon and oxygen isotopes in laterally extensive carbonate-cemented layers: implications for mode of growth and subsurface identification: Journal of Sedimentary Research, v. 69, p. 184-191.

Kushnir, J., AND Kastner, M., 1984, Two forms of dolomite occurrences in the Monterey Formation, California: concretions and layers-a comparative mineralogical, geochemical and isotopic study, in Garrison, R.E., Kastner, M., and Zenger, D.H., eds., Dolomites of the Monterey Formation and Other Organic-Rich Units: SEPM, Special Publication 41, p. 87-102

LAWRENCE, J.R., AND GIESKES, J.M., 1981, Constraints on water transport and alteration in the oceanic crust from isotopic composition of pore water: Journal of Geophysical Research, v. 86, p. 7924-7934.

LaWrence, J.R., AND TaViani, M., 1988, Extreme hydrogen, oxygen and carbon isotope anomalies in the pore waters and carbonates of the sediments and basalts from the Norwegian Sea: methane and hydrogen from the mantle?: Geochimica et Cosmochimica Acta, v. 52, p. 2077-2083.

Lawrence, J.R., Drever, J.I., Anderson, T.F., and Brueckner, H.K., 1979 Importance of alteration of volcanic material in the sediments of Deep Sea Drilling site 323: chemistry, ${ }^{18} \mathrm{O} /{ }^{16} \mathrm{O}$ and ${ }^{87} \mathrm{Sr} /{ }^{86} \mathrm{Sr}$ : Geochimica et Cosmochimica Acta, v. 43, p. 573-588.

LeEr, C.H., Elderfield, H., and Wilson, P.A., 2000, Cenozoic deep-sea temperatures and global ice volumes from $\mathrm{Mg} / \mathrm{Ca}$ in benthic foraminiferal calcite: Science, v. 287, p. 269-272.

Lohmann, K.C., 1988, Geochemical patterns of meteoric diagenetic systems and their application to studies of paleokarst, in James, N.P., and Choquette, P.W., eds., Paleokarst: New York, Springer-Verlag, p. 58-80.

Loyd, S.J., Berelson, W.B., Lyons, T.W., Hammond, D.E., and Corsetti, F.A., 2012, Constraining pathways of microbial mediation for carbonate concretions of the Miocene Monterey Formation using carbonate-associated sulfate: Geochimica et Cosmochimica Acta, v. 78, p. 77-98.

MarShall, J.D., 1982, Isotopic composition of displasive fibrous calcite veins: reversals in pore-water composition trends during burial diagenesis: Journal of Sedimentary Petrology, v. 52, p. 615-630.

Mertz, K.A., Jr., Demaison, G., And Garrison, R.E., 1983, Lithofacies, organic matter, and source rock potential: Sandholdt Member (middle Miocene), Monterey Formation, Northern Santa Lucia Mountains, California (abstract): American Association of Petroleum Geologists/SEPM, Pacific Section, Programs and Abstracts p. 113

Morad, S., And Eshete, M., 1990, Petrology, chemistry and diagenesis of calcite concretions in Silurian shales from central Sweden: Sedimentary Geology, v. 66, p. $113-134$.

Morton, R.A., AND LAND, L.S., 1987, Regional variations in formation water chemistry, Frio Formation (Oligocene), Texas Gulf Coast: American Association of Petroleum Geologists, Bulletin, v. 71, p. 191-206.

MozLEy, P.S., 1996, The internal structure of carbonate concretions in mudrocks: a critical evaluation of the conventional concentric model of concretion growth: Sedimentary Geology, v. 103, p. 85-91.

MozLey, P.S., AND BURNS, S.J., 1993, Oxygen and carbon isotopic composition of marine carbonate concretions: an overview: Journal of Sedimentary Petrology, v. 63, p. 73-83.

Murata, K.J., and NaKata, J.K., 1974, Cristobalitic stage in the diagenesis of diatomaceous shale: Science, v. 184 , p. 567-568.

Packard, E.L., 1916, Faunal studies in the Cretaceous of the Santa Ana mountains of southern California: University of California Publications, Bulletin of the Department of Geology, v. 9, p. 413-462

Passey, B.H., Levin, N.E., Cerling, T.E., Brown, F.H., and Eiler, J.M., 2010, Hightemperature environments of human evolution in East Africa based on bond ordering in paleosol carbonates: National Academy of Sciences, Proceedings, v. 107, p. 1124511249.

Perry, E.A., Gieskes, J.M., And Lawrence, J.R., 1976, Mg, Ca and ${ }^{18} \mathrm{O} /{ }^{16} \mathrm{O}$ exchange in the sediment-pore water system Hole 149, DSDP: Geochimica et Cosmochimica Acta, v. 40, p. 413-423.
Pirrie, D., and Marshall, J.D., 1991, Field relationships and stable isotope geochemistry of concretions from James Ross Island, Antarctica: Sedimentary Geology, v. 71, p. 137-150.

RAISWELL, R., AND FisheR, Q.J., 2000, Mudrock-hosted carbonate concretions: a review of growth mechanisms and their influence on chemical and isotopic composition: Geological Society of London, Journal, v. 157, p. 239-251.

Sass, E., Bein, A., and Almogi-Labin, A., 1991, Oxygen-isotope composition of diagenetic calcite in organic-rich rocks: evidence for ${ }^{18} \mathrm{O}$ depletion in marine anaerobic porewater: Geology, v. 19, p. 839-842.

Schauble, E.A., Ghosh, P., and EIler, J.M., 2006, Preferential formation of ${ }^{13} \mathrm{C}-{ }^{18} \mathrm{O}$ bonds in carbonate minerals, estimated using first-principles lattice dynamics: Geochimica et Cosmochimica Acta, v. 70, p. 2510-2529.

Schoellhamer, J.E., Kinney, D.M., Yerkes, R.F., And Vedder, J.G., 1954, Geologic map of the northern Santa Ana Mountains, Orange and Riverside Counties, California: U.S. Geological Survey, Oil and Gas Investigations Map, O.M. 154, sheet.

Schwalbach, J.R., and Bohacs, K.M., 1991, Depositional sequences in continental margin settings: hemipelagic and pelagic facies of the Monterey Formation, California (abstract): SEPM, Annual Theme Meeting, Continental Margins, Abstracts, p. 30

Shevenell, A.E., Kennett, J.P., And Lea, D.W., 2008, Middle Miocene ice sheet dynamics, deep-sea temperatures, and carbon cycling: a Southern Ocean perspective: Geochemistry, Geophysics, Geosystems, v. 9, 14 p.

Sinelli, G.A., Mozley, P.S., Tobin, H.J., Underwood, M.B., Hoffman, N.W., AND Bellew, G.M., 2007, Diagenesis, sediment strength, and pore collapse in sediment approaching the Nankai Trough subduction zone: Geological Society of America, Bulletin, v. 119 , p. $377-390$

SuRdam, R.C., AND Stanley, K.O., 1981, Diagenesis and migration of hydrocarbons in the Monterey Formation, Pismo syncline, California, in Garrison, R.E., and Douglas, R.G., eds., The Monterey Formation and Related Siliceous Rocks of California: SEPM, Pacific Section, Special Publication 52, p. 317-327.

Thiagarajan, N., Adkins, J., and Eiler, J., 2011, Carbonate clumped isotope thermometry of deep-sea corals and implications for vital effects: Geochimica et Cosmochimica Acta, v. 75, p. 4416-4425.

Thyne, G.D., AND Boles, J.R., 1989, Isotopic evidence for origin of the Moerak septarian concretions, New Zealand: Journal of Sedimentary Petrology, v. 59, p. 272 279.

Tripati, A.K., Eagle, R.A., Thiagarajan, N., Gagnon, A.C., Bauch, H., Halloran, P.R., AND EILER, J.M., 2010, ${ }^{13} \mathrm{C}-{ }^{18} \mathrm{O}$ isotope signatures and "clumped isotope" thermometry in foraminifera and coccoliths: Geochimica et Cosmochimica Acta, v. 74 , p. $5697-5717$

UREY, H.C., 1947, The thermodynamics properties of isotopic substances: Chemical Society of London, Journal, p. 562-581.

Vasconcelos, C., McKenzie, J.A., Warthmann, R., and Bernasconi, S.M., 2005 Calibration of the $\delta^{18} \mathrm{O}$ paleothermometer for dolomite precipitated in microbial cultures and natural environments: Geology, v. 33, p. 317-320.

Veizer, J., Ala, D., Azmy, K., Bruckschen, P., Buhl, D., Bruhn, F., Carden, G.A.F., Diener, A., Ebneth, S., Godderis, Y., Jasper, T., Korte, C., Pawellek, F., Podlaha, O.G., and Strauss, H., $1999,{ }^{87} \mathrm{Sr} /{ }^{86} \mathrm{Sr}, \delta{ }^{13} \mathrm{C}$ and $\delta^{18} \mathrm{O}$ evolution of Phanerozoic seawater: Chemical Geology, v. 161, p. 59-88.

White, R.J., Spinelli, G.A., Mozley, P.S., and Dunbar, N.W., 2011, Importance of volcanic glass alteration to sediment stabilization: offshore Japan: Sedimentology, y. 58 , p. $1138-1154$

Wilkinson, M., Crowley, S.F., and Marshall, J.D., 1992, Model for the evolution of oxygen isotope ratios in pore fluids of mudrocks during burial: Marine and Petroleum Geology, v. 9, p. 98-105.

ZaArur, S., Olack, G., and Affek, H.P., 2011, Paleo-environmental implications of clumped isotopes in land snail shells: Geochimica et Cosmochimica Acta, v. 75, 68596869

Received 18 May 2012; accepted 26 September 2012. 
APPENDIX 1.-Additional clumped isotope data from the sampled concretions.

\begin{tabular}{|c|c|c|c|c|c|c|}
\hline Sample & $\Delta_{47}$ & URF $\Delta_{47}$ & $\Delta_{47}-\mathrm{T}$ & URF $\Delta_{47}-\mathrm{T}$ & $\Delta_{48}$ & $\mathrm{n}$ \\
\hline MNC2-1 & $0.685+/-0.006$ & $0.750+/-0.006$ & $17.4+/-2.4$ & $17.1+/-2.4$ & 0.481 & 1 \\
\hline MNC2-2A & $0.678+1-0.009$ & $0.743+/-0.009$ & $18.8+/-2.7$ & $18.4+/-2.7$ & -0.240 & 1 \\
\hline MSCP-1 & $0.612+/-0.013$ & $0.673+/-0.013$ & $34.4+1-3.3$ & $33.2+1-3.3$ & 0.331 & 2 \\
\hline MMC8-RB & $0.659+/-0.007$ & $0.723+/-0.007$ & $28.0+/-2.5$ & $22.5+/-2.5$ & 0.199 & 2 \\
\hline ММС9-M & $0.627+1-0.007$ & $0.689+1-0.007$ & $34.7+/-2.5$ & $29.6+/-2.5$ & 0.285 & 1 \\
\hline HC2-B4 & $0.611+/-0.012$ & $0.673+/-0.012$ & $33.6+1-3.3$ & $33.3+/-3.3$ & 0.528 & 2 \\
\hline HC3-IRA & $0.598+/-0.013$ & $0.658+/-0.013$ & $35.6+1-3.3$ & $36.5+1-3.3$ & 0.542 & 1 \\
\hline
\end{tabular}

